\title{
Measuring The ECONOMIC IMPACT OF MONETARY UnION:
} The CASe OF OKINAWA

by

Shinji Takagi, Mototsugu Shintani, and Tetsuro Okamoto

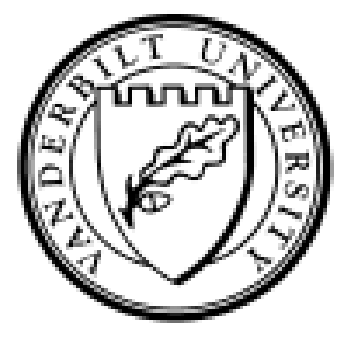

Working Paper No. 03-W15

July 2003

\author{
DEPARTMENT OF ECONOMICS \\ VANDERBILT UNIVERSITY \\ NASHVILLE, TN 37235
}

www.vanderbilt.edu/econ 


\title{
Measuring the Economic Impact of Monetary Union:
}

\section{The Case of Okinawa*}

\author{
Shinji Takagi, Mototsugu Shintani, and Tetsuro Okamoto
}

This version: July 2003

\begin{abstract}
Data from Okinawa's monetary union with the United States in 1958 and with Japan in 1972 are used to obtain a quantitative indication of how monetary union might affect the behavior of nominal and real shocks across two economies. With monetary union, the variance of the real exchange rate between two economies declines, and their business cycle linkage becomes stronger. A VAR analysis of output and price data for Okinawa and Japan further indicates that the contribution of asymmetric nominal shocks in business cycles becomes smaller. Monetary union thus seems to facilitate both nominal and real convergence.
\end{abstract}

JEL classification numbers: F33, F36, F15, E42

${ }^{*}$ Takagi (corresponding author): Independent Evaluation Office, International Monetary Fund, Washington, D.C. 20431, USA. e-mail: stakagi@imf .org . Shintani: Department of Economics, Vanderbilt University, Nashville, TN 37235, USA. e-mail: mototsugu. shintani@vanderbilt.edu . Okamoto: Faculty of Economics, Osaka Sangyo University, Osaka 574-8530, Japan. e-mail: okamoto@eco.osaka-sandai.ac.jp. Much of the research was completed while the first author was Professor of Economics at Osaka University. This research was supported by a grant from the Japanese Ministry of Education. The authors are grateful for the useful comments received on an earlier draft from Shinichi Fukuda, Fumio Hayashi, Hiroshi Yoshikawa, an anonymous referee, and John Campbell, editor of this Review. Needless to say, they assume full responsibility for the views expressed and errors that may remain. 


\section{Introduction}

The purpose of this paper is to measure the economic impact of monetary union by taking advantage of the unique monetary experience of Okinawa (the modern Japanese name for the geographical area covering the Ryukyu Islands). Because of its strategic importance, Okinawa was governed by the United States (US) occupation forces separately from the rest of Japan following the cessation of hostilities in World War II, and remained under US rule long after Japan had regained its sovereignty over the rest of its legitimate territory in 1952. Article 3 of the San Francisco Peace Treaty, while recognizing the implicit sovereignty of Japan over Okinawa, allowed the US to continue to exercise its administrative control over the islands for an indefinite period. During its 27-year period of US rule, Okinawa experienced two rounds of monetary union, once in September 1958 (when it was incorporated into the monetary system of the United States, with the US dollar becoming legal tender) and again in May 1972 (when the political sovereignty over Okinawa was returned to Japan).

Our interest in Okinawa naturally stems from the establishment of the European Economic and Monetary Union (EMU) in January 1999 and the recently heightened interest of the academic and policy-making communities in establishing a similar regional monetary arrangement in other parts of the world. In discussing the costs and benefits of monetary union for any region, the central issue concerns what will happen to the magnitude and frequency of asymmetric (or idiosyncratic) shocks across potential member countries (see, for example, Frankel and Rose, 1998). If monetary union causes the asymmetric shocks to diminish by facilitating real and nominal convergence, the need for individual countries to use a discretionary monetary policy may also diminish. On the 
other hand, monetary union may well increase the magnitude and incidence of asymmetric shocks if it promotes regional specialization. What will happen to the nature of asymmetric shocks is, therefore, an empirical question. In attempting to address this question, the experience of EMU, with its history of just a few years, is of limited help. This is where the experience of Okinawa becomes useful.

To be sure, there have been other instances of monetary union in modern history, including the German Currency Union of 1990 (see, for example, Bofinger, 1990; and Frowen and Holscher, 1997). However, the experience of Okinawa particularly seems to provide an analytical advantage for our purpose, because it presents not just one but two rounds of monetary union, both involving the integration of two market economies operating under fixed exchange rates, for which reasonably reliable price and output data exist. By quantitatively looking at the experience of Okinawa, we should be able to gain some understanding of what a monetary union would do to the nature of real and nominal shocks affecting two economies.

The rest of the paper is organized as follows. Section II provides a brief monetary history of Okinawa, including the establishment of the B-yen military note standard in July 1948, the replacement of the B-yen by the US dollar in September 1958, and the integration of Okinawa into the monetary system of mainland Japan in May 1972. Section III compares the variances of Okinawa's real exchange rates with Japan and the US across three monetary regimes, namely, the B-yen standard, the US-dollar standard, and the Japanese yen standard. Section IV examines the extent to which the monetary unification affected the manner in which the growth of Okinawa output was determined by the growth of Japanese and US outputs. Section V attempts to see 
how the behavior of asymmetric real and nominal shocks might have changed across alternative monetary regimes by fitting a vector autoregression (VAR) to the Okinawa-Japan data. Section VI presents concluding remarks. Finally, Appendix A summarizes the data used in the study, and Appendix B discusses the statistical properties of the VAR model in Section V.

\section{A Brief Monetary History of Okinawa, 1945-1972}

\section{A. The B-Yen Standard}

From the landing of the American forces in the spring of 1945 until July 1948, the monetary system of Okinawa was in disarray. Initially, the economy was virtually without money, and most economic transactions took place on a barter basis, often in units of value denominated in American cigarettes. With the restoration of normalcy, however, a monetary economy returned. The US military proclamation of March 25, 1946, stipulated that, effective April 15, Supplementary TypeB military yen (so-called B-yen) notes and new Bank of Japan notes would in principle be the only legal tender. ${ }^{1}$ This "bimetallic" standard was to last for some time. The proclamation of August 24, 1946, stipulating that new Bank of Japan notes would be the only legal tender on the main Okinawa island after September 1, 1946, ${ }^{2}$ was modified before it took effect by another military proclamation of August 8, 1947, which also made B-yen notes legal tender in all of Okinawa, effective August $1 .^{3}$

\footnotetext{
${ }^{1}$ The residents were required to surrender their old Bank of Japan notes in exchange for new Bank of Japan notes or B-yen military notes. In practice, only the B-yen notes (printed in Washington, D.C. in 1943 for use in occupied Japan) were given out, because the supply of new Bank of Japan notes was inadequate.

${ }^{2}$ According to Makino (1987), the US military preferred to use Bank of Japan notes because of the legal presumption that the military notes would become the liabilities of the US government. For its part, the Japanese government had guaranteed the US military forces virtually unlimited access to the use of Bank of Japan notes, given its obligation to bear the entire local cost of the US occupation in Okinawa.

${ }^{3}$ Makino (1987) lists several reasons for this measure, including the reduction in Japan's financial contribution
} 
The monetary system was unified in the summer of 1948. On June 26, 1948, the US military authorities issued a proclamation requiring the holders of new Bank of Japan notes and B-yen notes to surrender them in exchange for "new" currency notes (which would turn out to be the "existing" B-yen notes) between July 16 and July 20. Then, on July 20, B-yen military currency was officially announced to be the only legal tender in Okinawa, effective July 21. This measure was taken in view of the major shift in US policy towards a more permanent occupation of Okinawa as a military bastion in the Pacific. Simultaneously, on July 15, 1948, the Japanese Ministry of Finance issued an ordinance terminating the status of B-yen notes as legal tender in Japan. Thus, Okinawa became a monetary area which was separate from the rest of Japan, with its own currency and with its own central bank, the Bank of the Ryukyus which had just been established on May $1{ }^{4}$

With the establishment of the B-yen monetary system, greater discipline was introduced into the mechanism under which B-yen currency was issued. In principle, B-yen was issued in exchange for the sale of goods and services to the US military, the receipt of foreign aid and remittances, and the export of agricultural and other products by the local population. To formalize this mechanism, on April 12, 1950, a system was established whereby the counterpart US dollar proceeds were paid into the Ryukyus Dollar Commercial Account (established as the Revolving Fund Account on April 1, 1949; the name was changed to the Ryukyus Foreign Exchange Fund in June 1953) and the foreign exchange reserves were centrally managed by the US military government for import and other purposes. At this time, the multiple exchange rates were also unified at the exchange rate of BY120

to the maintenance of US occupation and the US military government's increasing fiscal need to finance the cost of procuring local services.

${ }^{4}$ From October 1950, the Bank of the Ryukyus was the only bank authorized to do foreign exchange business. 
per US dollar (or Y3 per B-yen), which were to be applied to both exports and imports. Because Japanese yen and B-yen had been convertible at par prior to July 1948, this change represented an almost 200 percent revaluation of the B-yen relative to the Japanese yen, although it was a devaluation against the US dollar.

In addition to the channel operating through the Ryukyus Dollar Commercial Account, Byen currency notes were also put into circulation or withdrawn from circulation through the fiscal operations of the US military government (renamed, in December 1950, the United States Civil Administration of the Ryukyu Islands, or USCAR). ${ }^{5}$ From 1951 to 1955, the principal instrument was the Counterpart Fund Account (established on April 1, 1951), into which B-yen sales proceeds of goods provided under the US aid program were paid. When an aid commodity was sold, for example, the equivalent value of B-yen was withdrawn from circulation.

From 1955 to 1957, the USCAR controlled the supply of B-yen notes through the commercial banking organ of the Bank of the Ryukyus. In particular, the USCAR pursued the policy of effectively sterilizing the inflows of foreign assets by borrowing the excess B-yen held by the Bank of the Ryukyus, which, in the absence of tradable government securities, effectively amounted to a sale of government securities to the public with a repurchase agreement. In conventional terms, transactions through the Dollar Commercial Account affected the foreign asset (FA) component, while the USCAR's fiscal operations determined the domestic credit (DC) component of the assets in the consolidated balance sheet of the Civil Administration Local Currency Funds and the central banking account of the Bank of the Ryukyus.

\footnotetext{
${ }^{5}$ Under the terms and directives set forth by the USCAR, the Government of the Ryukyu Islands (set up on April 1, 1952) performed administrative functions as the local governing body consisting of appointed and elected officials.
} 


\section{B. The US Dollar Standard}

On June 1, 1957, a fundamental shift was introduced into this system by the establishment of a Foreign Exchange Settlement Account. From this point on, an issue of B-yen was required to be backed by an equivalent value of US dollars. In other words, the central banking system of Okinawa was changed to a currency board, with the exchange rate of BY120 per US dollar (for a discussion of currency boards, see Williamson 1995). In terms of substance, it was only a short step to go from here to the complete monetary integration of Okinawa with the US economy in September 1958.

On August 23, 1958, the USCAR announced that the B-yen would be replaced by the US dollar and, according to the military ordinance of September 15, the holders of B-yen notes were required to surrender them in exchange for US dollar notes between September 16 and 20 (later extended to November 29, 1958). At this time, it was announced that this measure, coupled with the complete liberalization of trade, foreign exchange, and capital transactions, was meant to promote foreign direct investments, to expand international trade, and to improve the economy of Okinawa generally. ${ }^{6}$ The monopoly position of the Bank of the Ryukyus in the foreign exchange business was terminated, except that it was given the US Treasury's Custody Account to facilitate the smooth supply of US dollar cash.

\section{Steps Towards the Japanese Yen Standard}

\footnotetext{
${ }^{6}$ According to internal US government documents, in making the decision to replace the B-yen with the US dollar, the US authorities wished to avoid the possibility of embarrassing Congressional debate over the continued use of military currency so many years after the cessation of hostilities. It was also noted that the introduction of dollars would "eliminate any questions regarding the need for redemption of a Ryukyuan currency when the eventual return of the Ryukyu Islands to Japanese sovereignty takes place." See the USCAR documents on the introduction of US dollars, as archived in the Okinawa Prefectural Archives, Naha.
} 
With the declaration of US President John F. Kennedy in March 1962 that Okinawa would someday be returned to Japan, the handover of sovereignty over Okinawa to Japan became a realistic possibility. On November 22, 1969, the Japanese and US governments issued a joint statement, declaring that Okinawa would be returned to Japanese sovereignty on May 15, 1972; on June 17, 1971, a formal agreement was signed by both governments, paving the way for completing the process of transfer. About two months later, however, on August 28, the yen, pegged to the US dollar at the rate of Y360 since 1949, began to float, and the new central rate of Y308 per US dollar (amounting to a 16.88 percent revaluation) was established in the Smithsonian Agreement of December.

The devaluation of the US dollar complicated the process of Okinawa's monetary unification with Japan. In responding to the popular sentiments of the Okinawan people, on October 8, 1971, the Japanese government announced that it would effectively apply the old parity of Y360 per US dollar to the dollar cash and monetary deposits of individuals by making a compensation for the difference; the Government of the Ryukyu Islands ordered all the financial institutions in Okinawa to close on October 8 and 9 in order to certify the amount of deposits and cash held by individuals. On May 12, 1972, the Japanese Cabinet determined that the conversion rate would be Y305 per US dollar, slightly more favorable to the Okinawans than the closing market rate of Y303.75 per US dollar on that day, with the difference between Y360 and Y305 to be paid as a compensation in the case of the individual holders of US dollar cash and monetary deposits whose amount had previously been certified. The US dollar deposits were converted into yen deposits on May 15, while the US dollar cash was exchanged for yen between May 15 and 20. 


\section{Okinawa's Real Exchange Rates with Japan and the}

\section{United States}

The simplest way to examine the economic impact of monetary union would be to compare the behavior of Okinawa's consumer prices relative to those of Japan and the United States under different monetary regimes, namely, a monetary union, a fixed exchange rate regime, and (for the Okinawa-US pair only) a flexible exchange rate regime. Here, the relative price, or the real exchange rate, is defined as,

$$
q_{t}=p_{t}^{O}-p_{t}^{*}
$$

where $p_{t}^{O}$ and $p_{t}^{*}$ are, respectively, the logarithms of Okinawa's consumer price index and the foreign (Japanese or US) consumer price index, each multiplied by 100. Under a flexible exchange rate regime, the relative price would need to be adjusted for the nominal exchange rate. We will compare the variances of the real exchange rates across the B-yen period, the US dollar period and the Japanese yen period. ${ }^{7}$

First, for the B-yen period, two alternative periods are considered, namely, the full period July 1951-August 1958 (the month preceding the establishment of the US dollar standard) and the

\footnotetext{
${ }^{7}$ Okinawa was a highly open economy, with imports amounting to around 70 percent of gross income. Furthermore, despite the fact that it was separately administered, it was closely integrated into the Japanese economy in terms of trade structure, with more than 70 percent of import trade and almost 90 percent of export trade conducted with Japan in the 1960s. In order to accommodate Okinawa in its otherwise restrictive regime, the Japanese government gave special treatment to Okinawa in trade and payments under the so-called Japan-Ryukyu Trade Agreement of July 10, 1952, exempting, for example, sugar and pineapples, the two main export commodities, from the application of import tariff. Along with the United States, Japan provided a significant amount of financial assistance to help Okinawa finance its imports, which were roughly three times the value of its exports. Thus, we assume that any restrictions that may have existed to be minimal in external transactions between Okinawa and its two main trading partners.
} 
shorter period July 1951-May 1957 (the month preceding the establishment of the currency board system). Second, the US dollar period is set from October 1958 to July 1971, where the first two months are excluded to eliminate any possible initial turbulence. Finally, the Japanese yen period is set from August 1972 to December 2001. The beginning month is chosen so as to exclude the potentially disruptive initial months following the monetary union of May 1972.

Table 1 reports the variances of Okinawa's real exchange rates with Japan and the US. The variances are calculated in both levels $\left(q_{t}\right)$ and first differences $\left(\Delta q_{t}=q_{t}-q_{t-1}\right)$ for four different categories of goods, i.e., general, food, clothing, and housing. The standard errors of the variance estimates are also reported. Three things stand out from the table. First, for the real exchange rate between Okinawa and Japan, the smallest variances were generally observed during the Japanese yen period. The exceptions are the clothing price (in first difference) and the housing price (in level), although the latter anomaly may be discounted by a relatively large standard error. ${ }^{8}$ Second, for the real exchange rate between Okinawa and the US, the smallest variances were generally observed during the US dollar period, although the differences across the US dollar and the B-yen regimes were extremely small in first difference form. Not surprisingly, much larger variances were observed during the Japanese yen period, when the yen was floating against the US dollar. This observed correlation of nominal and real exchange rates under a flexible exchange rate regime is a well-known phenomenon in the literature (Mussa, 1986). Finally, despite the considerable real integration of

\footnotetext{
${ }^{8}$ In part, the clothing price anomaly is likely related to the following two factors. First, Japanese prices, and clothing prices in particular, displayed much greater short-term volatility during the post-1972 period, most notably during the high inflation periods of 1973-74 and 1979-80 but also more generally. In fact, the mean monthly percentage change in the clothing price index rose from 0.15 during July 1951-July 1971 to 0.29 during August 1972-December 2001; for Okinawa, the mean monthly percentage change rose from -0.07 to 0.29 . Second, the consumption baskets for clothing items differ considerably between mainland Japan and Okinawa because of the large climatic difference, minimizing the scope for convergence in disaggregated price indices.
} 
Okinawa with Japan and the fact that the yen was pegged to the US dollar, the Okinawa-US variances were generally smaller than the Okinawa-Japan variances during the US dollar period.

These results are reminiscent of those reported by Engel and Rogers (1996) in a context of flexible exchange rates, whereby the variation in relative prices is much smaller between two cities located in the same country than between equidistant cities located in different countries. What we find is a "common currency" effect: the variation in real exchange rates becomes smaller as one moves from the regime of fixed exchange rates to the regime of a common currency. A common currency thus has the effect of reducing the variance of the real exchange rate between two economies beyond what a credible fixed exchange rate regime would achieve.

\section{Determination of Okinawa's Output Growth}

Now that we have looked at the behavior of price linkages across regimes, the next logical step would be to look at the behavior of output linkages. One way to do so is to see how the linkage of business cycles may change across alternative monetary regimes. This is a topic of particular interest because the most often cited reason against monetary union is the loss of an independent monetary policy, which is considered desirable for dealing with a country-specific business cycle. If business cycles are similar across economies, there is less reason to maintain monetary independence, so that the cost of monetary union becomes smaller.

If we assume that the growth of Okinawa's output is largely determined by the growth of outputs in Japan and the US, we can estimate the following regression equation as a way of quantifying the impact of monetary union on the linkage of output variables between sets of two economies, 


$$
\Delta y_{t}^{O}=\alpha_{0}+\alpha_{1} \Delta y_{t}^{J}+\alpha_{2} M U_{t}^{J} \Delta y_{t}^{J}+\alpha_{3} \Delta y_{t}^{U S}+\alpha_{4} M U_{t}^{U S} \Delta y_{t}^{U S}+\varepsilon_{t}
$$

where $\Delta y_{t}^{O}\left(=y_{t}^{O}-y_{t-1}^{O}\right)$ is the annual growth rate of Okinawa's output, $\Delta y_{t}^{J}\left(=y_{t}^{J}-y_{t-1}^{J}\right)$ is the annual growth rate of Japanese output, $\Delta y_{t}^{U S}\left(=y_{t}^{U S}-y_{t-1}^{U S}\right)$ is the annual growth rate of US output, $M U_{t}^{J}$ and $M U_{t}^{U S}$ are slope dummies for Japanese monetary union (unity for 1972 and after; zero otherwise) and US monetary union (unity for 1959-1970; zero, otherwise), and $\varepsilon_{t}$ is a random error term. In this and the following sections, we use annual data because higher frequency data for Okinawa's output are not available.

We are particularly interested in the estimated values of the coefficients for the monetary union (MU) dummies. If the business cycle linkage is constant across monetary regimes, one would expect the coefficients of the MU dummies to be statistically insignificant. On the other hand, if Okinawa's output is affected more by Japanese (or US) output when the Japanese yen (or the US dollar) is legal tender in Okinawa, one would expect the coefficients to be positive and statistically significant. In actually estimating equation (2), we have included additional dummy variables to account for the discontinuity in data in 1971 and for the apparent structural decline in economic growth after 1974, as well as the annual growth rate of US defense expenditures in one specification (see Appendix A for details). In view of the possibility that Japanese or US output may affect Okinawa's output with a lag, we have also included their lagged values in our preliminary work, but found them to be statistically insignificant. Therefore, the reported results do not include the lagged values of Japanese and US outputs.

Table 2 summarizes the results of estimating equation (2) for 1956-2000 by ordinary least squares (OLS). Two specifications are reported, one with, and the other without, US defense expenditures; 
the results, however, are qualitatively the same in either specification. They show that the Japanese MU dummy is significantly positive and that the coefficient of the US MU dummy is also positive (though statistically insignificant). The weight of the evidence thus points to the possibility that monetary union facilitates a closer business cycle linkage between two economies, even beyond what a fixed exchange rate regime accomplishes (Baxter and Stockman, 1989). ${ }^{9}$

\section{Identifying the Real and Nominal Shocks by Vector}

\section{Autoregression}

Presumably, the nature of price and output linkages between two economies is determined by the incidence of asymmetric (or idiosyncratic) real and nominal shocks. There may be a presumption that, under monetary union, the variance of asymmetric money supply shocks will be smaller. On the other hand, there is no a priori presumption as to whether or not the variance of asymmetric real and money demand shocks will be smaller. One can easily imagine different scenarios in which the variance of real and money demand shocks increases, remains constant or decreases under monetary union. In the discussions of EMU in the European context, some have argued that asymmetric real shocks would increase under monetary union to the extent that it would promote greater regional specialization (see, for example, Wyplosz, 1997, and De Grauwe, 2000, for a discussion of these issues). ${ }^{10}$ Alternatively, such shocks may remain unchanged if they are caused predominantly by

\footnotetext{
${ }^{9}$ Baxter and Stockman (1989) show that business cycles in a large sample of economies became more countryspecific in the post-1973 period of flexible exchange rates.

${ }^{10}$ According to De Grauwe (2000, p. 24), this idea was initially developed by G. Myrdal and N. Kaldor and later refined by Paul Krugman.
} 
such independent factors as weather, technology, and taste; they may even decline if they are predominantly of monetary origin.

In this final section, we investigate the contributions of real and nominal shocks in the business cycle of Okinawa, by using the methodology of Blanchard and Quah (1989) to identify each type of shocks in a vector autoregression (VAR) framework. In what follows, given data limitation, we restrict our attention to a bivariate VAR model of relative output between Okinawa and Japan, $y_{t}=y_{t}^{O}-y_{t}^{J}$, and the relative price (or the real exchange rate) between Okinawa and Japan, $q_{t}=p_{t}^{O}-p_{t}^{J}$, where $p_{t}^{J}$ is the logarithm of the Japanese general price index (multiplied by 100). Unlike the Okinawa-US pair, no adjustment for the nominal exchange rate is required because Okinawa and Japan remained under a fixed exchange rate regime of one type or another throughout the sample period.

Following previous studies that employed the methodology of Blanchard and Quah (e.g., Bayoumi 1992; Ahmed, Ickes, Wang, and Yoo, 1993; and Clarida and Galí, 1994), we identify real shocks $\left(\varepsilon_{t}^{r}\right)$ and nominal shocks $\left(\varepsilon_{t}^{n}\right)$ in the structural model of the form:

$$
\left[\begin{array}{c}
\Delta y_{t} \\
q_{t}
\end{array}\right]=\left[\begin{array}{cc}
\theta_{11}(L) & \theta_{12}(L) \\
\theta_{21}(L) & \theta_{22}(L)
\end{array}\right]\left[\begin{array}{c}
\varepsilon_{t}^{r} \\
\varepsilon_{t}^{n}
\end{array}\right]
$$

with a long-run restriction $\theta_{12}(1)=0$, or $\gamma_{y q} \equiv \theta_{12}(1) / \theta_{22}(1)=0$, where $\theta_{12}(L)=\sum_{i=0}^{\infty} \theta_{12, i} L^{i}$ and the other terms are similarly defined. Here, we are using the term nominal shocks to describe the type of shocks that have no long-run impact on relative output, by analogy to the role of such shocks in a conventional closed economy model.

As in the previous section, we use the annual series from 1956 to 2000. Because of the limited 
number of observations for annual data, we estimate a bivariate VAR model of order one. Not only is this the simplest specification of a dynamic structure, it is also consistent with the literature on purchasing power parity (PPP) where an autoregressive model of order one is often applied to the real exchange rate, $q_{t}$, for the purpose of estimating the half-lives of deviations from PPP.

Figure 1 shows the impulse responses of output and price to the identified shocks with one standard error bands. Formulae for the standard errors of the estimators are provided in Appendix B. The response of relative output to real shocks is positive and permanent (panel A), while its response to nominal shocks is positive but transitory, given the imposed long-run restriction (panel B). On the other hand, the response of the relative price to real shocks is negative and transitory (panel C), while its response to nominal shocks is positive and transitory (panel D).

All the point estimates of the responses discussed above have signs that are consistent with what the standard aggregate supply and demand model would predict. According to the standard closed economy model, a positive real (supply) shock has a negative permanent price effect and a positive permanent output effect, while a positive nominal (demand) shock has a positive transitory output effect and a positive permanent price effect. It should be noted, however, that the price in our open economy case is a relative price or the real exchange rate. Therefore, the price effect is only transitory for both real and nominal shocks, given long-run PPP. In contrast, the direction of the output effect is the same for both closed and open economy models: the effect is positive and permanent for a real shock, and negative and transitory for a nominal shock.

In order to check the plausibility of the long-run restriction of the form $\gamma_{y q}=0$, we follow the procedure suggested by King and Watson (1997) whereby the sensitivity of the confidence bands 
for $\gamma_{y q}$ is examined to different sets of identifying assumptions. We thus compute the confidence bands for $\gamma_{y q}$ as functions of $\lambda_{q y}, \lambda_{y q}$ and $\gamma_{q y}$, where $\lambda_{q y}$ is the ratio of contemporaneous coefficients on $q_{t}$ and $\Delta y_{t}$ in the identified $\Delta y_{t}$ equation, $\lambda_{y q}$ is the ratio of contemporaneous coefficients on $\Delta y_{t}$ and $q_{t}$ in the identified $q_{t}$ equation, and $\gamma_{q y} \equiv \theta_{21}(1) / \theta_{11}(1)$ is the long-run (cumulative) effect of a real shock on $q_{t}$. Figure 2 shows the point estimates and 95 percent confidence intervals for $\gamma_{y q}$ for various values of $\lambda_{q y}$ (panel A), $\lambda_{y q}$ (panel B) and $\gamma_{q y}$ (panel C). A set of values on the horizontal axis in each panel is selected so that it captures the global shape of the confidence bands. Since the standard aggregate supply and demand model predicts a negative real effect on $q_{t}$ and a positive nominal effect on $\Delta y_{t}$ in the short-run, we expect $\lambda_{q y}$ to be negative and $\lambda_{y q}$ to be positive. We also expect $\gamma_{q y}$ to be negative unless the real shock has a reverse price effect. Therefore, panels A to $\mathrm{C}$ imply that the long-run restriction $\gamma_{y q}=0$ cannot be rejected for a reasonable range of values for these parameters, namely, $-2.5 \leq \lambda_{q y}<0,0<\lambda_{y q} \leq 2.5$, and $-12 \leq \gamma_{q y}<0$. In addition, panel D of Figure 2 shows the 95 percent confidence ellipse for $\left(\lambda_{q y}, \lambda_{y q}\right)$ constructed using the long-run restriction $\gamma_{y q}=0$.

The relative size of real and nominal shocks is shown in Table 3, which reports the estimated percentage of the forecast error variance in relative output growth explained by real shocks. For the entire sample period, the point estimates imply that the contribution of real shocks is more than 90 percent for all forecast horizons (see the first column). In order to see how the behavior of real and nominal shocks might have changed with the monetary union of 1972, we split the data into two periods, and separately estimate the VAR models (see the second and third columns). In view of the major break in output data in 1971 (see Appendix A for details), we consider the subsample 
1956-1970 as the pre-monetary union period, and the subsample 1971-2000 as the post-monetary union period. By testing the null hypothesis that the variance of real shocks is less than or equal to that of nominal shocks, we find that the hypothesis is rejected for the Japanese yen period at the one percent level of significance. On the other hand, the same hypothesis cannot be rejected for the first subsample that includes the B-yen and US dollar periods.

A word of caution is in order. While one may be tempted to consider this result as an evidence of the role of monetary union in reducing the effect of nominal shocks in the macroeconomic linkage of Okinawa and Japan, it turns out that the hypothesis that the variance of real shocks is greater than or equal to that of nominal shocks cannot be rejected, either, for either period because of a large standard error resulting from the small sample size of the first subsample. In addition, as Faust and Leeper (1997) point out, inference from a VAR model identified by the long-run restriction may not be reliable in finite sample. Thus, we can only be tentative in our conclusion. Subject to these limitations, however, the VAR analysis of this section seems to suggest that real shocks began to dominate nominal shocks following the monetary unification of Okinawa with Japan in the early 1970s. This implies that the contribution of asymmetric nominal shocks became smaller.

\section{Conclusion}

We have used the price and output data from Okinawa's monetary union with the US (in 1958) and with Japan (in 1972) to obtain quantitative evidence of how monetary union might affect the behavior of nominal and real shocks across two economies. First, an analysis of general and disaggregated consumer price indices has shown that, with monetary union, the variances of 
Okinawa's real exchange rates with Japan and the US declined. Second, an OLS estimation of Okinawa's output determination has suggested that its business cycle linkage with Japan (and, to a much lesser extent, the US) was stronger under monetary union. Finally, a VAR analysis of output and price data for Okinawa and Japan has provided some evidence that the incidence of asymmetric nominal shocks became smaller following the monetary unification of the two economies.

It should be noted, however, that underlying structural factors can change with monetary union, so that we cannot attribute all the difference to a change inherent in the monetary union itself. For example, in the context of Okinawa, the Japanese government began in 1972 to inject a massive amount of financial resources into the Okinawan economy in order to raise its income level closer to the level prevailing in the mainland. Thus, the closer real integration observed between mainland Japan and Okinawa after 1972 may be a result more of that economic policy than of the monetary union itself.

Even so, it seems significant that a closer (albeit weak) business cycle linkage was also observed between Okinawa and the United States under the US dollar standard, and that no major discrete change in the trade regime was observed at the time of either monetary unification. These observations give some credence to the view that monetary union promotes real convergence independently of any concurrent policy shift and beyond the convergence produced by the trade promotion effect of exchange rate stability, as stressed recently by Frankel and Rose (1998). Given the evidence of smaller real exchange rate variances, stronger business cycle linkages, and less dominant asymmetric nominal shocks, we may conclude, with some reservation, that monetary union by itself facilitates both nominal and real convergence. 


\section{References}

Ahmed, Shaghil, Barry W. Ickes, Ping Wang, and Byung Sam Yoo, "International Business Cycles," American Economic Review 83 (June 1993), 335-359.

Bank of the Ryukyus, Sengo Okinawa Keizai Shi [Postwar Economic History of Okinawa] (Naha, Okinawa, 1984).

Bank of the Ryukyus, Ryukyu Ginko Sanjugonen Shi [35-Year History of the Bank of the Ryukyus] (Naha, Okinawa, 1985).

Baxter, Marianne, and Alan C. Stockman, "Business Cycles and the Exchange-Rate Regime: Some International Evidence," Journal of Monetary Economics 23 (May 1989), 377-400.

Bayoumi, Tamim, "The Effect of the ERM on Participating Economies," IMF Staff Papers 39 (June 1992), 330-356.

Blanchard, Olivier Jean, and Danny Quah, "The Dynamic Effects of Aggregate Demand and Supply Disturbances," American Economic Review 79 (September 1989), 655-673.

Bofinger, Peter, "The Germany Monetary Unification (GMU): Converting Marks to D-Marks," Federal Reserve Bank of St. Louis Review 72 (July/August 1990), 17-36.

Clarida, Richard, and Jordi Galí, "Sources of Real Exchange-Rate Fluctuations: How Important Are Nominal Shocks?" Carnegie-Rochester Conference Series on Public Policy 41 (December 1994), 1-56.

De Grauwe, Paul, Economics of Monetary Union, fourth edition (Oxford: Oxford University Press, 2000).

Engel, Charles, and John H. Rogers, "How Wide Is the Border?" American Economic Review 86 (December 1996), 1112-1125.

Faust, Jon, and Eric M. Leeper, "When Do Long-Run Identifying Restrictions Give Reliable Results?" Journal of Business and Economic Statistics 15 (July 1997), 345-353.

Frankel, Jeffrey A., and Andrew K. Rose, "The Endogeneity of the Optimum Currency Area Criteria," Economic Journal 108 (July 1998), 1009-1025.

Frowen, Stephen F., and Jens Holscher (eds.), The German Currency Union of 1990: A Critical Assessment (London: Macmillan, 1997).

Government of the Ryukyu Islands, Ryukyu Shiryo [Ryukyu Documents] Vol. 6, (Naha, Okinawa, 1961).

Japanese Economic Planning Agency, National Economic Accounts Quarterly, quarterly issues. 
Japanese Management and Coordination Agency, Bureau of Statistics, Monthly Report of Retail Prices, monthly issues.

Kabira, Nario, "Sengo Okinawa Tsuka Hensen no Kento [An Examination of Postwar Currency Developments in Okinawa]," University of the Ryukyus Economic Review 42 (September 1991), 87-103.

King, Robert G., and Mark W. Watson, "Testing Long-Run Neutrality," Federal Reserve Bank of Richmond Economic Quarterly 83 (Summer 1997), 69-101.

Lütkepohl, Helmut, "Asymptotic Distributions of Impulse Response Functions and Forecast Error Variance Decompositions of Vector Autoregressive Models," Review of Economics and Statistics 72, (February 1990), 116-125.

Makino, Hirotaka, Sengo Okinawa no Tsuka [The Currencies of Postwar Okinawa], Volumes 1 and 2 (Naha, Okinawa: Hirugisha, 1987).

Mussa, Michael, "Nominal Exchange Rate Regimes and the Behavior of Real Exchange Rates: Evidence and Implications," Carnegie-Rochester Conference Series on Public Policy 25 (Autumn 1986), 117-213.

United States Department of Commerce, Survey of Current Business, monthly issues.

United States Department of Labor, Monthly Labor Review, monthly issues.

Williamson, John, What Role for Currency Boards? (Washington, DC: Institute for International Economics, 1995).

Wyplosz, Charles, "EMU: Why and How It Might Happen," Journal of Economic Perspectives 11 (Fall 1997), 3-22.

Yoshino, Toshihiko, "Ryukyu no Kinyu Seido [The Financial System of the Ryukyus]," Kinyu Keizai, Bank of the Ryukyus (March 1960), 25-39. 
Table 1. Variances of Okinawa's Monthly Real Exchange Rates with Japan and the United States under Three Monetary Regimes

\begin{tabular}{|c|c|c|c|c|c|c|c|c|}
\hline \multirow{4}{*}{$\begin{array}{l}\text { Type of } \\
\text { consumer } \\
\text { price index }\end{array}$} & \multicolumn{8}{|c|}{ Monetary regime } \\
\hline & \multicolumn{4}{|c|}{ B-yen period } & \multirow{2}{*}{\multicolumn{2}{|c|}{$\begin{array}{c}\begin{array}{c}\text { US dollar } \\
\text { period }\end{array} \\
\text { (Oct 1958- } \\
\text { Jul 1971) }\end{array}$}} & \multirow{2}{*}{\multicolumn{2}{|c|}{$\begin{array}{c}\text { Japanese yen } \\
\text { period }\end{array}$}} \\
\hline & \multicolumn{2}{|c|}{$\begin{array}{l}\text { (Jul 1951- } \\
\text { Aug 1958) }\end{array}$} & \multicolumn{2}{|c|}{$\begin{array}{l}\text { (Jul 1951- } \\
\text { May 1957) }\end{array}$} & & & & \\
\hline & $q_{t}$ & $\Delta q_{t}$ & $q_{t}$ & $\Delta q_{t}$ & $q_{t}$ & $\Delta q_{t}$ & $q_{t}$ & $\Delta q_{t}$ \\
\hline & & & With & apan: & & & & \\
\hline General & $\begin{array}{l}115.6 \\
(13.6)\end{array}$ & $\begin{array}{l}2.7 \\
(0.6)\end{array}$ & $\begin{array}{l}114.7 \\
(13.1)\end{array}$ & $\begin{array}{c}2.7 \\
(0.7)\end{array}$ & $\begin{array}{c}58.8 \\
(4.8)\end{array}$ & $\begin{array}{c}1.7 \\
(0.3)\end{array}$ & $\begin{array}{c}5.9 \\
(0.3)\end{array}$ & $\begin{array}{c}0.2 \\
(0.0)\end{array}$ \\
\hline Food & $\begin{array}{l}113.4 \\
(12.4)\end{array}$ & $\begin{array}{c}6.6 \\
(1.9)\end{array}$ & $\begin{array}{l}108.1 \\
(12.5)\end{array}$ & $\begin{array}{c}7.0 \\
(2.2)\end{array}$ & $\begin{array}{l}98.6 \\
(7.5)\end{array}$ & $\begin{array}{c}5.8 \\
(1.0)\end{array}$ & $\begin{array}{l}15.2 \\
(1.3)\end{array}$ & $\begin{array}{l}1.0 \\
(0.1)\end{array}$ \\
\hline Clothing & $\begin{array}{c}63.7 \\
(10.9)\end{array}$ & $\begin{array}{c}3.2 \\
(0.8)\end{array}$ & $\begin{array}{c}75.8 \\
(12.1)\end{array}$ & $\begin{array}{c}3.6 \\
(0.9)\end{array}$ & $\begin{array}{l}121.6 \\
(9.6)\end{array}$ & $\begin{array}{c}0.7 \\
(0.1)\end{array}$ & $\begin{array}{l}15.1 \\
(1.3)\end{array}$ & $\begin{array}{c}3.3 \\
(0.8)\end{array}$ \\
\hline Housing & $\begin{array}{l}225.8 \\
(27.0) \\
\end{array}$ & $\begin{array}{c}0.9 \\
(0.2) \\
\end{array}$ & $\begin{array}{l}224.4 \\
(24.5) \\
\end{array}$ & $\begin{array}{c}1.0 \\
(0.2) \\
\end{array}$ & $\begin{array}{l}75.9 \\
(7.3) \\
\end{array}$ & $\begin{array}{c}1.3 \\
(0.5) \\
\end{array}$ & $\begin{array}{l}86.5 \\
(3.3) \\
\end{array}$ & $\begin{array}{c}0.2 \\
(0.0) \\
\end{array}$ \\
\hline & & & With & ne US: & & & & \\
\hline General & $\begin{array}{l}57.5 \\
(5.9)\end{array}$ & $\begin{array}{c}1.9 \\
(0.5)\end{array}$ & $\begin{array}{l}46.3 \\
(5.9)\end{array}$ & $\begin{array}{c}2.1 \\
(0.7)\end{array}$ & $\begin{array}{l}15.9 \\
(1.2)\end{array}$ & $\begin{array}{c}1.4 \\
(0.2)\end{array}$ & $\begin{array}{l}493.3 \\
(26.3)\end{array}$ & $\begin{array}{c}8.9 \\
(0.8)\end{array}$ \\
\hline Food & $\begin{array}{l}59.6 \\
(6.1)\end{array}$ & $\begin{array}{c}4.4 \\
(1.3)\end{array}$ & $\begin{array}{l}40.5 \\
(5.5)\end{array}$ & $\begin{array}{c}5.1 \\
(1.6)\end{array}$ & $\begin{array}{l}25.3 \\
(3.1)\end{array}$ & $\begin{array}{c}5.0 \\
(0.9)\end{array}$ & $\begin{array}{l}472.7 \\
(24.8)\end{array}$ & $\begin{array}{l}10.2 \\
(0.9)\end{array}$ \\
\hline Clothing & $\begin{array}{c}99.8 \\
(21.6)\end{array}$ & $\begin{array}{c}3.1 \\
(0.9)\end{array}$ & $\begin{array}{l}110.2 \\
(23.1)\end{array}$ & $\begin{array}{c}3.6 \\
(1.0)\end{array}$ & $\begin{array}{l}19.0 \\
(1.8)\end{array}$ & $\begin{array}{c}0.7 \\
(0.1)\end{array}$ & $\begin{array}{c}1450.0 \\
(72.8)\end{array}$ & $\begin{array}{l}13.6 \\
(1.2)\end{array}$ \\
\hline Housing & $\begin{array}{l}46.1 \\
(5.3) \\
\end{array}$ & $\begin{array}{c}0.5 \\
(0.1) \\
\end{array}$ & $\begin{array}{l}42.4 \\
(4.8) \\
\end{array}$ & $\begin{array}{c}0.6 \\
(0.1) \\
\end{array}$ & $\begin{array}{l}12.2 \\
(1.2)\end{array}$ & $\begin{array}{c}1.4 \\
(0.5)\end{array}$ & $\begin{array}{l}431.3 \\
(23.8)\end{array}$ & $\begin{array}{c}9.1 \\
(0.8) \\
\end{array}$ \\
\hline Sample size & 86 & 85 & 71 & 70 & 154 & 153 & 353 & 352 \\
\hline
\end{tabular}

$q_{t}$ and $\Delta q_{t}$ are the levels and first differences, respectively, of the natural logarithms of real exchange rates, multiplied by 100 . Each price index is seasonally adjusted. Numbers in parentheses are standard errors 
Table 2. Okinawa's Annual Output Growth Regression

\begin{tabular}{lcc}
\hline \hline Explanatory variables & Without defense & With defense \\
\hline Constant & $10.08^{*}$ & $10.90^{*}$ \\
& $(2.22)$ & $(2.28)$ \\
Japanese output growth & -0.15 & -0.23 \\
& $(0.26)$ & $(0.26)$ \\
Japanese monetary union & $0.72^{*}$ & $0.75^{*}$ \\
$\times$ Japanese output growth & $(0.27)$ & $(0.27)$ \\
US output growth & 0.21 & 0.21 \\
& $(0.25)$ & $(0.25)$ \\
US monetary union & 0.21 & 0.15 \\
$\times$ US output growth & $(0.38)$ & $(0.38)$ \\
1971 dummy & $-11.06^{*}$ & $-10.67^{*}$ \\
& $(3.08)$ & $(3.07)$ \\
1974-2000 dummy & $-9.32^{*}$ & $-10.11^{*}$ \\
& $(1.85)$ & $(1.93)$ \\
US defense growth & - & 0.12 \\
& - & $(0.09)$ \\
\hline \multirow{2}{*}{ Durbin-Watson statistic } & 2.53 & 2.63 \\
& & \\
\hline
\end{tabular}

The sample period is from 1956 to 2000 (sample size 45). Numbers in parentheses are standard errors. ${ }^{*}$ indicates that the coefficient is significant at the five percent level. 
Table 3. Forecast Error Variance Decomposition: Percentage of Output Variance Accounted for by Real Shocks

\begin{tabular}{|c|c|c|c|c|c|c|}
\hline \multirow{3}{*}{$\begin{array}{l}\text { Horizon } \\
1 \text { year }\end{array}$} & \multirow{2}{*}{\multicolumn{2}{|c|}{$\begin{array}{c}\text { Full sample } \\
1956-2000\end{array}$}} & \multicolumn{4}{|c|}{ Subsample } \\
\hline & & & \multicolumn{2}{|c|}{$1956-1970$} & \multicolumn{2}{|c|}{$\begin{array}{c}1971-2000 \\
\end{array}$} \\
\hline & 92.6 & $(26.3)$ & 58.2 & $(83.6)$ & 96.5 & $(6.2)$ \\
\hline 5 years & 92.0 & (25.7) & 56.6 & (73.0) & 95.0 & (6.1) \\
\hline 10 years & 91.9 & $(25.7)$ & 56.5 & $(72.0)$ & 95.0 & (6.1) \\
\hline 20 years & 91.9 & $(25.7)$ & 56.5 & (71.1) & 95.0 & (6.1) \\
\hline
\end{tabular}

Standard errors are in parentheses. 
Figure 1. Output and Price Responses to Real and Nominal Shocks

A. Output Response to Real Shocks

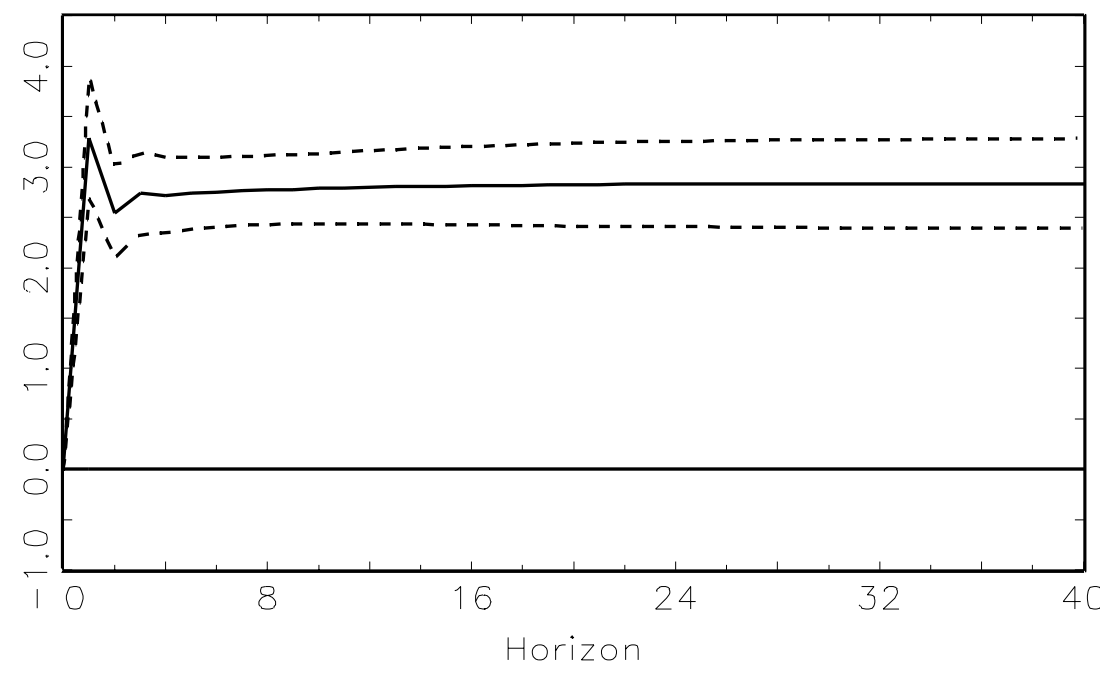

C. Price Response to Real Shocks

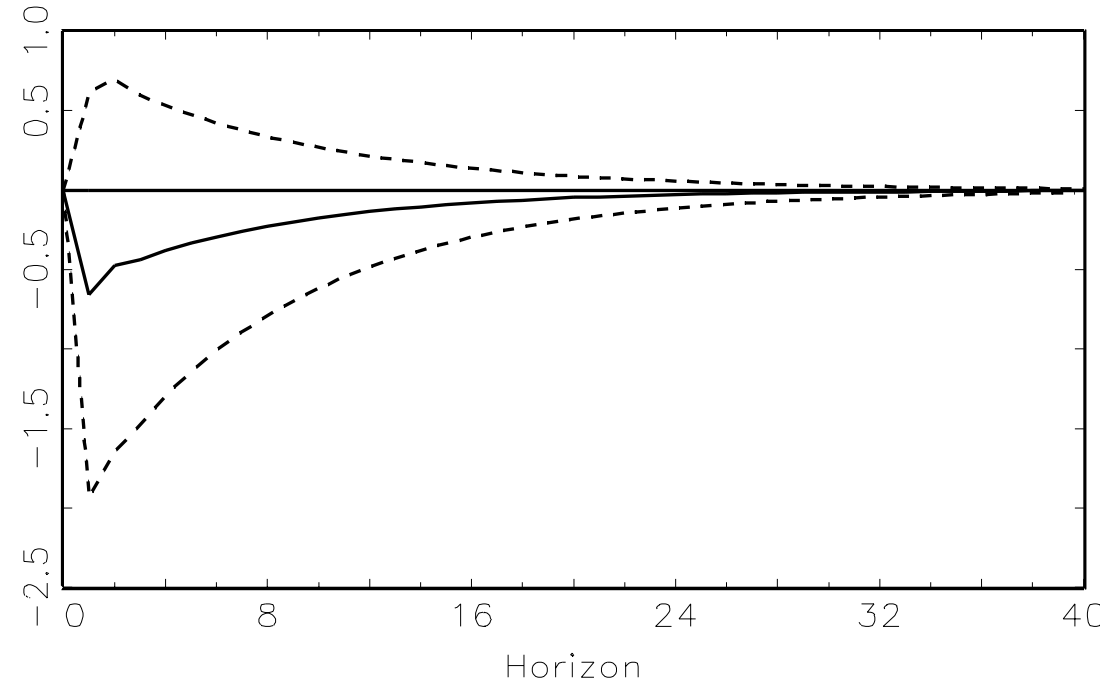

B. Output Response to Nominal Shocks

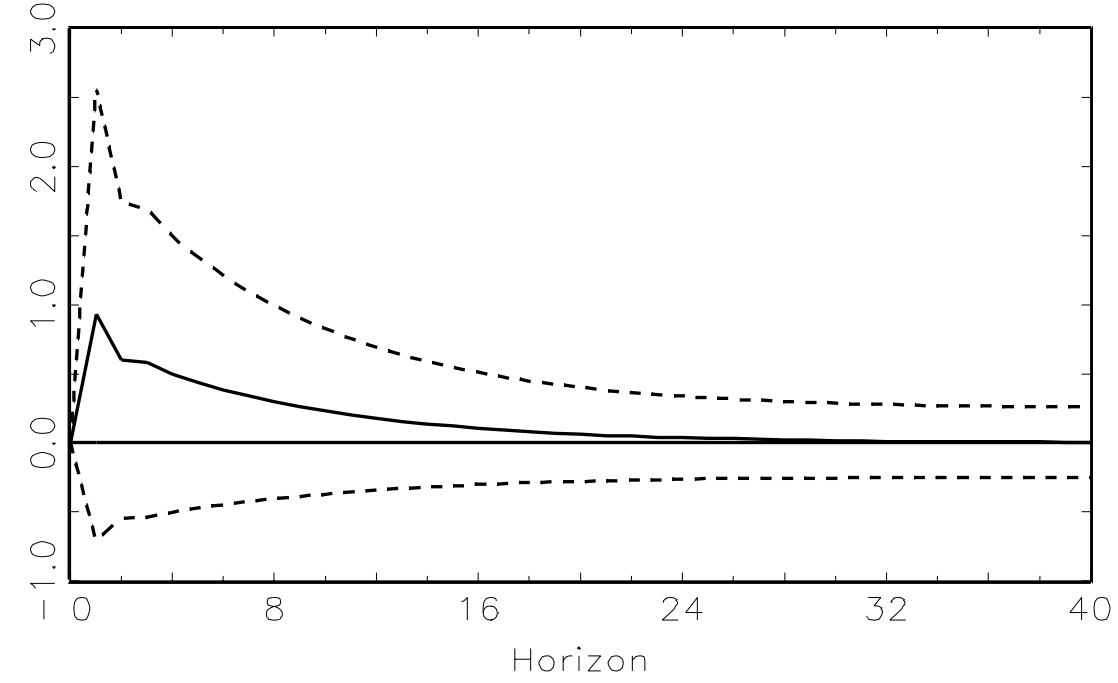

D. Price Response to Nominal Shocks

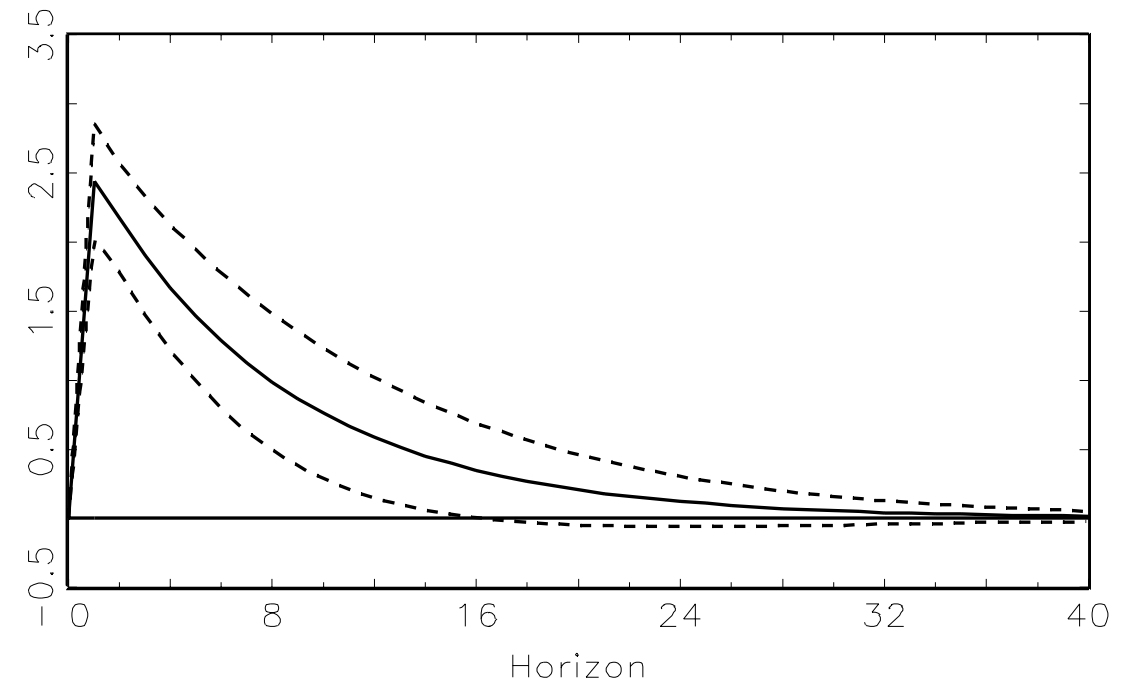


Figure 2. Sensitivity of the Long-Run Identifying Assumption

A. $95 \%$ Confidence Interval for $\gamma_{y a}$ as a function of $\lambda_{\text {ay }}$

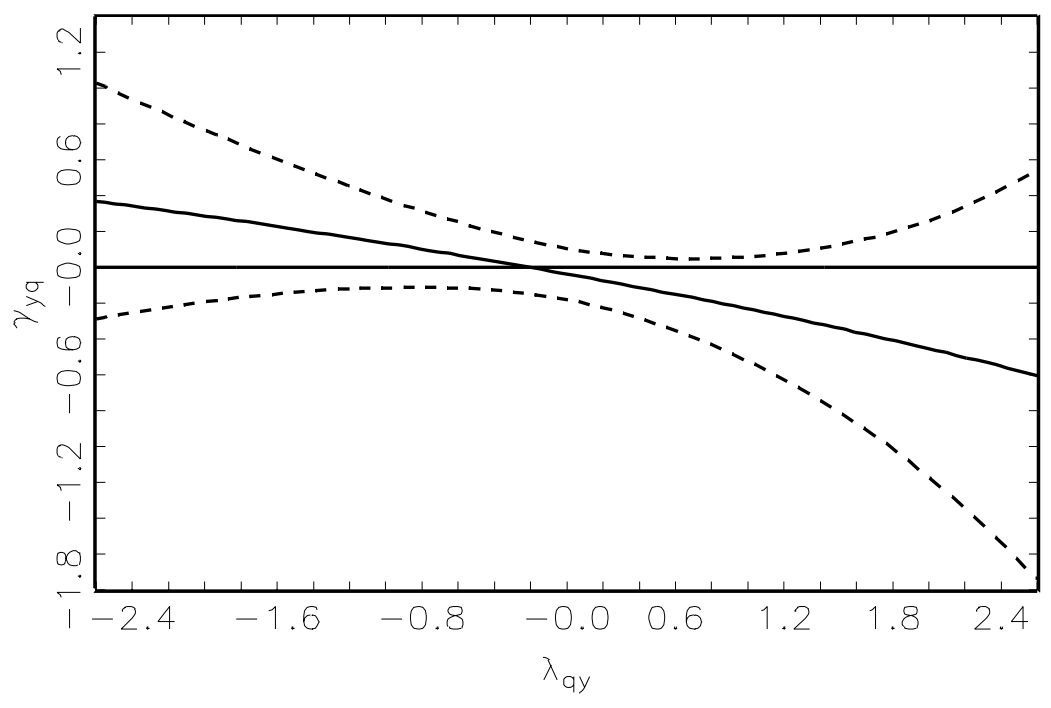

C. $95 \%$ Confidence Interval for $\gamma_{y a}$ as a function of $\gamma_{\text {qy }}$

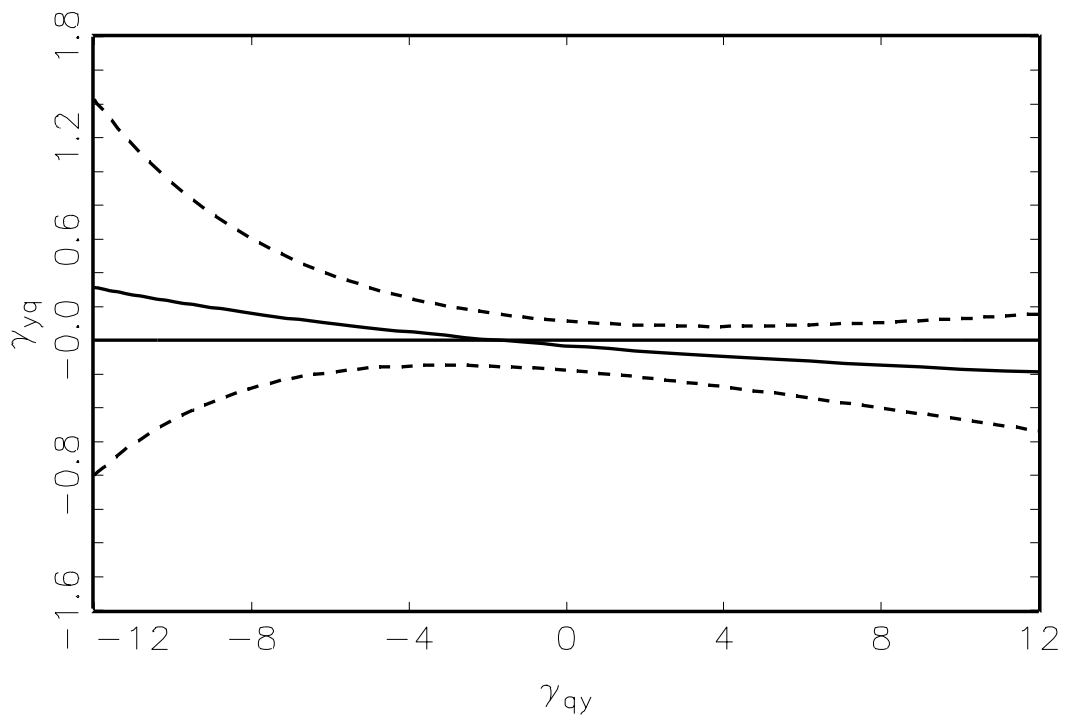

B. $95 \%$ Confidence Interval for $\gamma_{y a}$ as a function of $\lambda_{y a}$

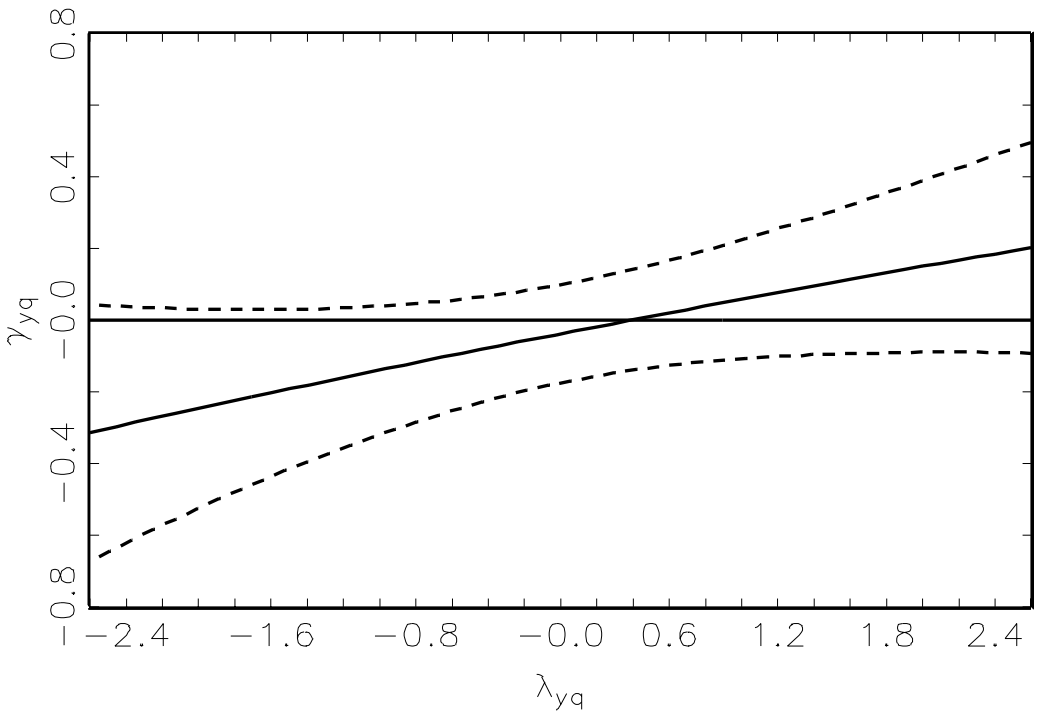

D. $95 \%$ Confidence Ellipse when $\gamma_{y q}=0$

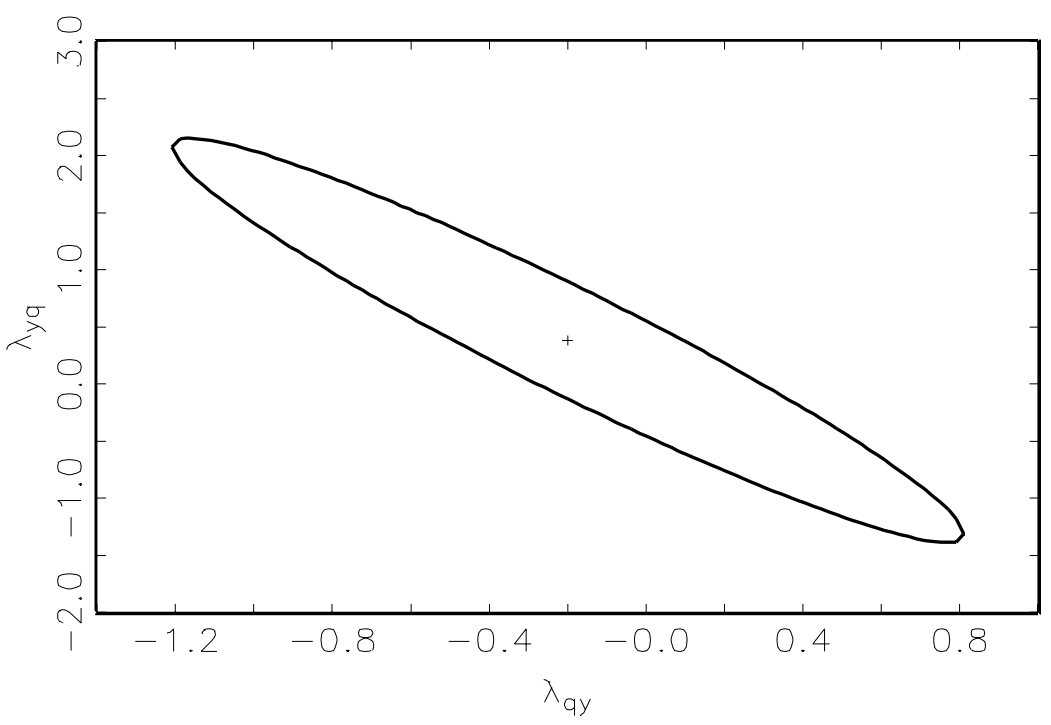




\section{Appendix A: Sources of Data}

The consumer prices for Japan and post-1972 Okinawa are obtained from the Bureau of Statistics, Japanese Management and Coordination Agency, Monthly Report of Retail Prices, monthly issues. For Japan, these are the price indices for all areas during the B-yen and US dollar periods and the price indices for major cities during the Japanese yen period; the indices for major cities are chosen for the final period in order not to include the Okinawa prices. The price indices for pre1972 Okinawa are from the proprietary data provided by the Okinawa Prefectural Government. For Okinawa, the indices are for the capital city of Naha only. The X12-ARIMA method has been applied to Japanese and Okinawa's price series, in order to remove seasonality as well as the effects of the introduction of consumption tax in April 1989 and its rate increase in April 1997. The seasonally adjusted series of the consumer price indices for the United States are obtained from the Bureau of Labor Statistics, US Department of Labor, Monthly Labor Review, monthly issues.

The real output data for Japan and the United States are the real GNP series (available on a quarterly basis) obtained from the Japanese Economic Planning Agency, National Economic Accounts Quarterly, quarterly issues, and the US Department of Commerce, Survey of Current Business, monthly issues, respectively. Quarterly data for US defense expenditures come from the Bureau of Economic Analysis, US Department of Commerce. For Okinawa, the real output figures are obtained by deflating the nominal gross expenditure figures (available only on a fiscal year basis) by the Naha consumer price index for the corresponding fiscal year. The nominal data come from the Bank of the Ryukyus (1984) for the pre-1971 period and from the Japanese Economic Planning Agency, National Economic Accounts Quarterly, quarterly issues, for the post-1971 period. ${ }^{11}$

Caution is required as the definition of fiscal year changed when Okinawa returned to Japanese sovereignty. From 1954 to 1970 (the last year under the old series), the fiscal year began in July and ended in June (e.g., fiscal 1954 covers the July 1954-June 1955 period). Since 1971 (the first year under the new series), the fiscal year has begun in April and ended in March (e.g., fiscal 1971 covers the April 1971-March 1972 period). This means that the months of April, May and June 1971 are included both in the ending part of fiscal 1970 and in the beginning part of fiscal 1971. In view of this, the annual output figures for Japan and the United States are created by adding up the relevant quarterly figures in an appropriate manner.

\section{Appendix B: Statistical Properties of the VAR Model in Section V}

This appendix derives some theoretical results required to construct error bands and test statistics used in the VAR analysis part of the main text. In general, a stationary $\operatorname{VAR}(p)$ process of $K \times 1$

\footnotetext{
${ }^{11}$ Note that the breakpoint for the output data is 1971, and not 1972, as the old series ends in June 1971 and the new series goes back to April 1971.
} 
vector of variables, $X_{t}$, can be written as

$$
A(L) X_{t}=u_{t}
$$

where $A(L)=I_{K}-\sum_{i=1}^{p} A_{i} L^{i}$ with the determinantal equation $|A(z)|=0$ having all its roots outside the unit circle, and $u_{t}$ is $K \times 1$ white noise with nonsingular covariance matrix $E\left(u_{t} u_{t}^{\prime}\right)=\Sigma_{u}$. To identify the structural shocks, $\varepsilon_{t}$, Blanchard and Quah (1989) utilized a restriction of recursive structure on the long-run multiplier, $\Theta(1)$, in

$$
X_{t}=\Theta(L) \varepsilon_{t}
$$

where $\Theta(L)=\sum_{i=0}^{\infty} \Theta_{i} L^{i}$ and $E\left(\varepsilon_{t} \varepsilon_{t}^{\prime}\right)=I_{K}$. To be more specific, the impulse response function, $\Theta_{i}$, is given by

$$
\Theta_{i}=C_{i} A(1) \Theta(1)
$$

where $C_{0}=I_{K}, C_{i}=\sum_{j=1}^{i} C_{i-j} A_{j}$ for $i \geq 1$ and $\Theta(1)$ is the lower triangular Cholesky decomposition satisfying $\Theta(1) \Theta(1)^{\prime}=A(1)^{-1} \Sigma_{u} A(1)^{-1 \prime}$. The $h$-period-ahead forecast error variance decomposition of variable $j$ due to $k$-th identified shocks is defined as

$$
\omega_{j k, h}=\sum_{i=0}^{h-1}\left(e_{j}^{\prime} \Theta_{i} e_{k}\right)^{2} / \operatorname{MSE}_{j}(h)
$$

where $e_{j}$ is a $j$-th column of $I_{K}$ and $\operatorname{MSE}_{j}(h)=\sum_{i=0}^{h-1} e_{j}^{\prime} \Theta_{i} \Theta_{i}^{\prime} e_{j}$. In what follows, we employ the notations from Lütkepohl (1990):

$$
\begin{aligned}
\alpha & =\operatorname{vec}\left(A_{1}, \ldots, A_{p}\right) \quad\left(K^{2} p \times 1\right) \\
\mathbf{A} & =\left[\begin{array}{ccccc}
A_{1} & A_{2} & \cdots & A_{p-1} & A_{p} \\
I_{K} & 0 & \cdots & 0 & 0 \\
0 & I_{K} & & 0 & 0 \\
\vdots & & \ddots & & \vdots \\
0 & 0 & \cdots & I_{K} & 0
\end{array}\right] \quad(K p \times K p) \\
\sigma & =\operatorname{vech}\left(\Sigma_{u}\right)
\end{aligned}
$$

As usual, vec denotes a column stacking operator and vech is a corresponding operator that stacks the elements on and below the diagonal. $\mathbf{L}_{m}$ is a $\left(m(m+1) / 2 \times m^{2}\right)$ elimination matrix such that $\operatorname{vech}(F)=\mathbf{L}_{m} \operatorname{vec}(F)$ for any $(m \times m)$ square matrix $F$. $\mathbf{D}_{m}$ is a $\left(m^{2} \times m(m+1) / 2\right)$ duplication matrix, such that $\operatorname{vec}(F)=\mathbf{D}_{m} \operatorname{vech}(F)$ for any $(m \times m)$ symmetric matrix $F$. The generalized inverse of $\mathbf{D}_{m}$ is defined by $\mathbf{D}_{m}^{+}=\left(\mathbf{D}_{m}^{\prime} \mathbf{D}_{m}\right)^{-1} \mathbf{D}_{m}^{\prime}$. $\mathbf{K}_{m n}$ is a $(m n \times m n)$ commutation matrix, such that $\operatorname{vec}\left(F^{\prime}\right)=\mathbf{K}_{m n} \operatorname{vec}(F)$ for any $(m \times n)$ matrix $F, J=\left[I_{K} 0 \ldots 0\right]$ is a $(K \times K p)$ matrix and $\iota$ is a $(p \times 1)$ vector of ones.

The asymptotic properties of the estimators for the Blanchard-Quah model are summarized in the following proposition. 
Proposition B1. $\quad$ Suppose

$$
\sqrt{T}\left(\begin{array}{c}
\hat{\alpha}-\alpha \\
\hat{\sigma}-\sigma
\end{array}\right) \stackrel{d}{\rightarrow} N\left[0,\left[\begin{array}{cc}
\Sigma_{\alpha} & 0 \\
0 & \Sigma_{\sigma}
\end{array}\right]\right]
$$

where $\Sigma_{\alpha}=\Gamma^{-1} \otimes \Sigma_{u}, \Gamma$ is the second moment matrix of $\left(X_{t}^{\prime}, \ldots, X_{t-p+1}^{\prime}\right)^{\prime}$ and $\Sigma_{\sigma}=2 \mathbf{D}_{K}^{+}\left(\Sigma_{u} \otimes\right.$ $\left.\Sigma_{u}\right) \mathbf{D}_{K}^{+\prime}$. Then

(i) $\quad \sqrt{T} \operatorname{vech}(\widehat{\Theta}(1)-\Theta(1)) \stackrel{d}{\rightarrow} N\left(0, Q \Sigma_{\alpha} Q^{\prime}+\bar{Q} \Sigma_{\sigma} \bar{Q}^{\prime}\right)$,

where

$$
\begin{aligned}
& Q= 2 H\left(A(1)^{-1} \Sigma_{u} A(1)^{-1 \prime} \otimes A(1)^{-1}\right)\left(\iota^{\prime} \otimes I_{K^{2}}\right), \\
& \bar{Q}= H\left(A(1)^{-1} \otimes A(1)^{-1}\right) \mathbf{D}_{K}, \quad \text { and } \\
& H=\left\{\mathbf{L}_{K}\left(I_{K^{2}}+\mathbf{K}_{K K}\right)\left(\Theta(1) \otimes I_{K}\right) \mathbf{L}_{K}^{\prime}\right\}^{-1} \mathbf{D}_{K}^{+}, \\
& \text {(ii) } \quad \sqrt{T} \operatorname{vec}\left(\widehat{\Theta}_{i}-\Theta_{i}\right) \stackrel{d}{\rightarrow} N\left(0, R_{i} \Sigma_{\alpha} R_{i}^{\prime}+\bar{R}_{i} \Sigma_{\sigma} \bar{R}_{i}^{\prime}\right),
\end{aligned}
$$

where

$$
\begin{aligned}
R_{i}= & \left(I_{K} \otimes C_{i} A(1)\right) \mathbf{L}_{K}^{\prime} Q-\left(\Theta(1)^{\prime} \otimes C_{i}\right)\left(\iota^{\prime} \otimes I_{K^{2}}\right)+\left(\Theta(1)^{\prime} A(1)^{\prime} \otimes I_{K}\right) G_{i}, \\
\bar{R}_{i}= & \left(I_{K} \otimes C_{i} A(1)\right) \mathbf{L}_{K}^{\prime} \bar{Q}, \quad \text { and } \\
G_{i}= & \sum_{m=0}^{i-1} J\left(\mathbf{A}^{\prime}\right)^{i-1-m} \otimes C_{m}, \\
& \quad \text { iii) } \quad \sqrt{T}\left(\widehat{\omega}_{j k, h}-\omega_{j k, h}\right) \stackrel{d}{\rightarrow} N\left(0, s_{j k, h} \Sigma_{\alpha} s_{j k, h}^{\prime}+\bar{s}_{j k, h} \Sigma_{\sigma} \bar{s}_{j k, h}^{\prime}\right),
\end{aligned}
$$

where

$$
\begin{aligned}
s_{j k, h}= & \frac{2}{\operatorname{MSE}_{j}(h)^{2}} \sum_{i=0}^{h-1}\left[\operatorname{MSE}_{j}(h)\left(e_{j}^{\prime} C_{i} A(1) \Theta(1) e_{k}\right)\left(e_{k}^{\prime} \otimes e_{j}^{\prime}\right) R_{i}\right. \\
& \left.-\left(e_{j}^{\prime} C_{i} A(1) P e_{k}\right)^{2} \sum_{m=0}^{h-1}\left(e_{j}^{\prime} C_{m} \Sigma_{u} \otimes e_{j}^{\prime}\right) G_{m}\right], \\
\bar{s}_{j k, h}= & \frac{1}{\operatorname{MSE}_{j}(h)^{2}} \sum_{i=0}^{h-1}\left[2 \mathrm{MSE}_{j}(h)\left(e_{j}^{\prime} C_{i} A(1) \Theta(1) e_{k}\right)\left(e_{k}^{\prime} \otimes e_{j}^{\prime}\right) \overline{R_{i}}\right. \\
& \left.-\left(e_{j}^{\prime} C_{i} A(1) \Theta(1) e_{k}\right)^{2} \sum_{m=0}^{h-1}\left(e_{j}^{\prime} C_{m} \otimes e_{j}^{\prime} C_{m}\right) \mathbf{D}_{K}\right] .
\end{aligned}
$$

Proof. Since $\Theta(1), \Theta_{i}$ and $\omega_{j k, h}$ are continuously differentiable functions of $\alpha$ and $\sigma$, the as- 
ymptotic distribution can be obtained by using the delta method. Analytical expressions of the derivatives required for the delta method are obtained by using the techniques employed in Lütkepohl (1990). For example, part (i) uses the fact that, for a symmetric positive definite $(m \times m)$ matrix $\Omega$ and a lower triangular $(m \times m)$ matrix $P$ such that $P P^{\prime}=\Omega$,

$$
\frac{\partial \operatorname{vech}(P)}{\partial \operatorname{vech}(\Omega)^{\prime}}=\left\{\mathbf{L}_{m}\left(I_{m^{2}}+\mathbf{K}_{m m}\right)\left(P \otimes I_{m}\right) \mathbf{L}_{m}^{\prime}\right\}^{-1}
$$

Applying this formula to $P=\Theta(1)$ and $\Omega=A(1)^{-1} \Sigma_{u} A(1)^{-1 \prime}$ and using the chain rule to derive $Q=\partial \operatorname{vech}(\Theta(1)) / \partial \alpha^{\prime}$ and $\bar{Q}=\partial \operatorname{vech}(\Theta(1)) / \partial \sigma^{\prime}$ yield the result. 